\title{
A MOCINHA DESVIANTE EM GLORIA PEREZ: UM ESTUDO SOBRE A CONSTRUÇÃO DE PERSONAGENS EM TELENOVELAS BRASILEIRAS
}

\author{
THE DEVIATING “GOOD GIRL” IN GLORIA PEREZ: A STUDY ABOUT THE \\ CONSTRUTION OF CHARACTERS IN BRAZILIAN SOAP OPERAS
}

\author{
Frederico de Mello Brandão Tavares*, Matheus Effgen Santos*
}

\begin{abstract}
Resumo
O presente trabalho busca compreender o modelo de construção de personagens empregado por Gloria Perez na criação das protagonistas femininas de suas telenovelas, tendo como recorte um estudo da personagem Ritinha, de A Força do Querer (2017). A pesquisa partiu da recuperação dos perfis de protagonistas anteriores da autora e utilizou como recurso metodológico o estudo das falas das personagens da mais recente obra de Perez, problematizando, a partir de Ritinha, complexidades da tensão entre protagonismo e autoralidade. Os resultados apontam para a configuração de uma personagem que dilui as barreiras entre o protagonismo e o antagonismo ao apresentar um perfil considerado desviante diante das mocinhas convencionais do melodrama televisivo nacional.
\end{abstract}

Palavras-chave: Ficção. Gloria Perez. Personagem. Telenovela.

\section{Abstract}

This text seeks understand the type of character's constrution used by Gloria Perez to the creation of yours female main characters in soap operas, having as a delimitation, a study about the character Ritinha, of A Força do Querer (2017). The research starts from the recuparation about the profiles of the previous main characters of the author. As methodological resource the study focus about the character's speech of the most recent work of Gloria Perez, problematizing, from Ritinha, complexities of the tension between protagonism and authorship. The results appoints the configuration of a character that dilutes the barrier between protagonism and antagonism in presenting a profile considered deviating in the face of the conventionals "good girls" in the brazilian television melodrama.

\footnotetext{
* Doutor em Ciências da Comunicação pela Universidade do Vale do Rio dos Sinos (UNISINOS), com licença de Pós-Doutorado junto à Universidade Nacional de La Plata (UNLP, Argentina). Jornalista e Mestre pela Universidade Federal de Minas Gerais (UFMG). Professor da Universidade Federal de Ouro Preto (UFOP), onde atua no curso de Graduação em Jornalismo e no Programa de PósGraduação em Comunicação. E-mail: fredtavares.ufop@gmail.com.

* Mestrando em Comunicação pela Universidade Federal do Espírito Santo (UFES). Bolsista da Fundação de Amparo à Pesquisa e Inovação do Espírito Santo (Fapes). Jornalista graduado pela Universidade Federal de Ouro Preto (UFOP). E-mail: matheuseffgen@gmail.com.
} 
Keywords: Fiction. Gloria Perez. Character. Soap Opera.

Datas de submissão e aprovação do artigo

Submissão: $21 / 5 / 2020$

Aceito: $22 / 8 / 2020$

\section{INTRODUÇÃO}

As personagens representam um dos componentes mais expressivos das telenovelas, pois é através de sua ação que o público pode compreender com mais clareza o enredo do qual elas fazem parte. Sua influência também se estende para além da tela, isso faz com que seja comum que as falas e os elementos de caracterização desses seres ficcionais extrapolem o vídeo e sejam reproduzidos nas ruas.

No Brasil, a criação destas figuras está a cargo dos(as) autores(as) que, em geral, acumulam as funções de escritores(as) e roteiristas das produções. A definição das características que formam essas personagens, sobretudo aquelas que protagonizam as tramas, é feita de acordo com uma mescla que envolve a trajetória artística e inclusive pessoal que cada autor(a), atrizes e atores. Na ficção seriada em geral, é possível que se encontrem em diferentes obras escritas pelo(a) mesmo(a) profissional, estilos de composição semelhantes no texto (PICADO; SOUZA, 2018) ou continuidades em aspectos internos da composição das obras (TEIXEIRA; SOUZA, 2019). Principalmente quando algum desses modelos de personagem obteve boa repercussão em trabalhos anteriores.

Também, num contexto histórico permeado por matrizes de referência, o melodrama e os tensionamentos a ele, perpassam e explicam uma certa historicidade da telenovela nacional. A compreensão dessa forma de comunicação, suas continuidades e rupturas, deve ser considerada (LOPES, 2009).

No contexto brasileiro, a autora Gloria Perez se estabeleceu como uma das principais realizadoras no campo das telenovelas devido ao seu trabalho na Rede Globo de Televisão. A autora também é conhecida por escrever integralmente suas telenovelas, evidência que demonstra ser mais precisa a identificação de um "modelo" para personagens exclusivamente seu, com menor interferência de terceiros(as), pelo menos em relação à escrita. Em seus trabalhos de ficção seriada televisiva, um tipo especial de personagem tem sido recorrente e marcante: a protagonista feminina.

Em A Força do Querer, seu último trabalho, telenovela produzida e exibida pela Rede Globo em 2017 na faixa das 21 horas, o enredo mostra a busca das personagens na realização de seus desejos e a convivência com os resultados das escolhas que faziam para alcançá-los. A história foi protagonizada por três 
personagens femininas: Bibi (Juliana Paes), Jeiza (Paolla Oliveira) e Ritinha (Isis Valverde).

Ritinha destacou-se. Pareceu romper com a fronteira entre as características de protagonistas e antagonistas. 0 gosto pela liberdade e a vontade de experimentar as mais variadas situações e diferentes lugares eram suas principais motivações. Porém, a maneira inconsequente como buscava satisfazer essas vontades a colocava diante de situações problemáticas. Há em Ritinha, numa impressão primeira sobre essa protagonista, a proposta de uma resistência em aceitar as opiniões das outras personagens, o que faz com que sejam produzidas distintas interpretações sobre ela dentro da obra.

Diante disso, este trabalho busca compreender o processo de construção do protagonismo feminino no texto de Gloria Peres, partindo do estudo da personagem Ritinha da telenovela $A$ Força do Querer. Buscou-se identificar quais foram as características da personagem mais recorrentes em suas falas e nas falas das demais figuras daquela trama, a fim de compreender como, a partir de um protagonismo desviante, se constrói uma personagem e ao mesmo tempo se organiza uma forma de articulação narrativa para uma certa história. Protagonistas complexas, caso de Ritinha, auxiliam, como ponto de partida, em uma compreensão de aspectos que carregam traços de uma autoria, de uma inscrição do(a) autor(a) em um enredo. Sua contextualização, frente a uma trajetória autoral encarnada em outras personagens, em uma obra extensa (um conjunto de telenovelas), dá a ver singularidades de uma certa época, de uma certa produção e, ao mesmo tempo, uma atualidade referente a essa maneira subjetiva de escrita, cercada de tensões e disputas.

Realizou-se uma análise textual, feita a partir da transcrição de todas as cenas nas quais a protagonista esteve presente ou foi citada. Estudou-se o texto das cenas, seus modos de enunciação e conteúdos, com o propósito de identificar: 1) a descrição que Ritinha fez de si mesma em suas falas, 2) as impressões que ela despertou nas demais personagens da telenovela, e 3) os diálogos/interações construídos envolvendo personagens e protagonista. Como recorte analítico, foram selecionados três momentos da novela, a saber: do capítulo 1 ao 10, do 111 ao 120 e, por último, do 163 ao 172. Essa escolha teve como referência o método apresentado por Maria Carmem Souza (2004), que defende a eleição dos momentos da história que apresentam um maior número de evidências da influência autoral após a observação prévia da trama.

\section{AS PROTAGONISTAS DE GLORIA PEREZ}

O primeiro trabalho de Gloria Perez como escritora de telenovelas ocorreu em 1983, quando foi convidada pela autora titular de Eu Prometo, Janete Clair, para ser uma de suas assistentes. Como Clair faleceu enquanto a trama era exibida, coube a Perez a função de concluir o texto como autora substituta sob a supervisão de Dias Gomes. 
0 reconhecimento por esse trabalho foi suficiente para alçá-la como autora titular das histórias que ela mesma desenvolveu. Em 30 anos, de 1987 a 2017, assinou sozinha o texto de nove produções: Carmem (1987), Barriga de Aluguel (1990), De Corpo e Alma (1992), Explode Coração (1995), O Clone (2001), América (2005), Caminha das Índias (2009), Salve Jorge (2012) e A Força do Querer (2017). Em todas, a autora concedeu a uma personagem feminina a centralidade da narrativa.

Em Carmem, a protagonista é uma jovem moradora no subúrbio carioca que tem como uma das principais características o desejo pela liberdade. Após ter uma desilusão amorosa, decide se vingar e fazer um pacto com a pomba gira para conseguir prestígio e poder, além de atrair todos os homens. Só havia uma condição para a continuidade do pacto: Carmem (Lucélia Santos) não poderia se apaixonar por nenhum deles ${ }^{1}$.

As vantagens logo se tornam um fardo quando ela descumpre o acordo e não consegue desfazer o pacto. Como consequência, a pomba gira se apossa de seu corpo e passa a se relacionar com os homens que ela desejava. Nesse período, Carmem se envolveu com o consumo de drogas, prostituição e chegou a ser presa. No desfecho da telenovela, a protagonista foi assassinada por José (Paulo Gorgulho), que sempre foi apaixonado por ela, mesmo antes do pacto. No último capítulo, o personagem se torna agressivo por não estar ao lado de Carmem, que insiste que é livre e que por isso não ficaria com ele?2.

Em Barriga de Aluguel, Clara (Claudia Abreu) é descrita como a ingênua que se acha espertíssima, audaciosa e que consegue manter a resiliência mesmo com os problemas que a interpelam. Apesar da maneira com que mente, a personagem representou a ingenuidade. Por conta de sua origem humilde, enxerga na chance de se tornar uma "barriga de aluguel" a oportunidade de conseguir dinheiro. Para levar o plano adiante, ela esconde o fato de sua família.

Com o desenvolvimento da gestação, a trama mostra os conflitos emocionais pelos quais ela passa ao se envolver com a criança que estava sendo gestada. Durante a gravidez, ela também se aproxima do pai da criança, Zeca (Victor Fasano), que fica em dúvida entre manter seu casamento com Ana (Cassia Kis Magro) ou iniciar uma nova relação com Clara. Após o nascimento da criança, Clara chega a fugir com ela por medo de que Ana ficasse com sua guarda e a impedisse de vê-la. No final da história, que chegou a ter seu rumo votado entre os(as) espectadores(as), as duas resolvem extrajudicialmente encontrar uma solução para o impasse ${ }^{3}$ e sem que nenhuma tivesse que abrir mão da convivência com a criança.

A personagem protagonista em De Corpo e Alma é Paloma, interpretada por Cristiana Oliveira. Diferente das outras protagonistas, a personagem não é de origem

\footnotetext{
${ }^{1}$ Disponível em: http://teledramaturgia.com.br/carmem/ Acesso em 22 de Abr. 2020.

2 Disponível em: https://observatoriodatelevisao.bol.uol.com.br/historia-da-tv/2017/10/ha-30-anosestreava-a-novela-carmem Acesso em 22 de Abr. 2020.

3 Disponível em: http://memoriaglobo.globo.com/programas/entretenimento/novelas/barriga-dealuguel/galeria-de-personagens.htm Acesso em 22 de Abr. 2020.
} 
humilde. É caracterizada como contida e como alguém que possui um grande senso de dever ${ }^{4}$. A sua trajetória se liga à história central quando ela recebe o transplante de coração de Bettina (Bruna Lombardi), que morre após de se desentender com Diogo (Tarcísio Meira), um homem casado com quem ela mantinha um relacionamento. Depois de recuperada, Paloma se sente no dever de procurar a família da doadora. Ao conhecer Diogo, ela também se apaixona por ele sem saber de seu envolvimento com Bettina.

A protagonista de Explode Coração foi Dara (Tereza Seiblitz), uma jovem cigana que, apesar de se orgulhar de sua origem, lutava para que pudesse ter mais liberdade em relação aos costumes de seu povo, que permitiam, por exemplo, que seus pais escolhessem para ela um noivo sem a necessidade do seu consentimento. Contrariando as tradições, resolve estudar escondida e faz um curso de prévestibular.

A trama ganha uma nova problemática quando ela, por meio da internet, conhece e se apaixona por Júlio (Edson Celulari). A partir desse ponto, e pelo fato dele ser casado, aumentam as dificuldades no relacionamento com sua família. Dara decide se manter afastada mas sofre com isso, situação que a faz ceder, terminar a relação com Júlio e aceitar o casamento arranjado com Igor (Ricardo Macchi). Apoiada pelo marido, ela esconde de todos o fato de que ela não se casou virgem, como prevê a tradição cigana, e que esperava um filho com Júlio. No fim da novela, Igor deixa Dara livre para viver com Júlio 5 .

A história principal de $O$ Clone atravessa a trama de Jade (Giovanna Antonelli), uma jovem filha de pais muçulmanos que nasceu e cresceu no Brasil. É descrita como uma mulher decidida, forte, romântica, astuciosa e esperta. Um dos seus maiores conflitos internos está no fato de que ela não se sentia completamente brasileira e nem muçulmana, além de lidar com os desafios para que uma mulher na sua condição se sentisse realizada 6 .

No início da ficção, ela se apaixona por Lucas (Murilo Benício) com quem é impedida de permanecer por conta da rigidez com a qual sua família seguia as tradições da religião. Eles são afastados depois que a mãe de Jade morre e ela passa a viver na casa de seu Tio, Ali (Stênio Garcia), que mora no Marrocos. Mais tarde, quando já estão casados com outras pessoas e com filhos, eles se reencontram e precisam enfrentar essas barreiras novamente para ficarem juntos, o que só acontece no final da trama.

Sol (Deborah Secco), protagonista de América, é uma jovem brasileira identificada como impetuosa, extrovertida que se entende como racional, mas que

\footnotetext{
${ }^{4}$ Disponível em: http://memoriaglobo.globo.com/programas/entretenimento/novelas/de-corpo-ealma/galeria-de-personagens.htm Acesso em 22 de Abr. 2020.

5 Disponível em: http://memoriaglobo.globo.com/programas/entretenimento/novelas/explodecoracao/trama-principal.htm Acesso em 22 de Abr. 2020.

6 Disponível em: https://memoriaglobo.globo.com/entretenimento/novelas/o-clone/tramaprincipal/ Acesso em 22 de Abr. 2020.
} 
se atrapalha com suas emoções. Possui temperamento fantasioso, tem sede de vida, de emoções e não deseja se prender a nada para ser bem-sucedida.

Mesmo estando apaixonada por Tião (Murilo Benício), Sol resolve partir de maneira ilegal rumo os EUA em busca de melhores condições financeiras. A protagonista começa a perceber as dificuldades da imigração ilegal ao ser impedida duas vezes de entrar no país. Ainda assim, ela decide fazer outra tentativa e apesar de ser mais uma vez flagrada pela polícia, consegue escapar e entrar no país. Para fugir da polícia e conseguir a permanência no país, Sol se aproxima e planeja um casamento de fachada com Ed (Caco Ciocler). Com o tempo, os dois se apaixonam e têm um filho.

Sol é deportada novamente após as denúncias de May (Camila Morgado), exnoiva de Ed, à polícia. Para não ser afastada do filho, a protagonista decide mentir e dizer que o pai do filho que esperava era Tião. No fim da história, com tudo esclarecido, Sol termina a trama ao lado de Ed, no Brasil' 7 .

Caminho das Índias conta a história de Maya (Juliana Paes) uma jovem indiana da casta de comerciantes, descrita como forte, alegre e bem-humorada. Destinada a se casar com Raj (Rodrigo Lombardi), marido escolhido por sua família, ela se apaixona por Bahuan (Márcio Garcia) e mesmo após descobrir que ele é um dalit casta que segundo as regras do hinduísmo é inferior e não pode sequer ser tocada decide fugir para os Estados Unidos com ele, que desiste da ideia e a deixa para trás. Logo após, ela descobre estar grávida. Como forma de evitar um escândalo, decide manter seu casamento com Raj, tendo que esconder, com a ajuda de sua mãe, a verdadeira paternidade de seu filho da família de seu marido e conviver com as regras rígidas impostas na nova casa ${ }^{8}$.

Morena (Nanda Costa), a heroína de Salve Jorge, como é descrita, foi criada somente pela mãe no Complexo do Alemão, no Rio de Janeiro. As duas se revezam nos cuidados do filho de Morena, que nunca foi reconhecido pelo pai. Como precisou trabalhar cedo para cuidar da criança, ela é conhecida por sua personalidade forte. Logo no início da história, aceita uma proposta para um trabalho a ser realizado na Turquia por medo de perder a casa em que mora com a família. No entanto, ao chegar no país, descobre que foi enganada por uma quadrilha que traficava mulheres e as obrigava a se prostituírem.

O objetivo principal da personagem passa a ser o desmonte do esquema de tráfico de pessoas, sem que isso represente algum risco para sua família. Em meio a essas dificuldades, precisou lidar com a relação conturbada com seu namorado, Theo (Rodrigo Lombardi), que não acreditava na existência do tráfico de mulheres?.

\footnotetext{
${ }^{7}$ Disponível em: https: / /observatoriodatelevisao.bol.uol.com.br/historia-da-tv/2018/03/ha-13-anosestreava-anovela-america Acesso em 22 de Abr. 2020.

8 Disponível em: https://observatoriodatelevisao.bol.uol.com.br/historia-da-tv/2018/01/caminhodas-indiasestreava-ha-nove-anos Acesso em 22 de Abr. 2020.

9 Disponível em: https://memoriaglobo.globo.com/entretenimento/novelas/salve-jorge/tramaprincipal/ Acesso em 22 de Abr. 2020.
} 
De maneira geral, a composição das personalidades dessas protagonistas comporta características marcadas pela imprudência, exemplificadas pelo uso da mentira e da omissão diante de situações importantes. A partir desse resgate é possível ainda destacar alguns outros traços em comum entre essas personagens: são jovens, desafiam valores em busca de sua liberdade, enxergam o trabalho como um caminho para a independência e como forma de apoiar suas famílias, buscam explorar novos lugares e culturas.

Gomes (2013) observou a construção das personagens protagonistas de Gloria Perez, nas quais, segundo ela, há um deslocamento no que tange a temática amorosa:

Herdeira de Janete Clair, a roteirista ancora os amores de seus protagonistas nas bases do melodrama, com destaque para o lugar da mulher que é atualizado: representada como uma fortaleza, capaz das maiores peripécias em nome de seus projetos individuais, entretanto, quando estão com seus amores, assumem a representação mais convencional: mãe, esposa dedicada, romântica e sensivel (GOMES, 2013, p. 87) ${ }^{10}$.

Sobre a relação dessas protagonistas com o antagonismo, não há uma determinação. Existem alguns casos em que foi possível a identificação de uma personagem (ou mais) como sendo antagonista principal como em Explode Coração, Barriga de Aluguel, América e Salve Jorge. Já nos casos de Carmem, De Corpo e Alma, O Clone e Caminho das Índias não se identificou o antagonismo em uma personagem específica.

\section{PERSONAGEM, PROTAGONISMO E FICÇÃO}

A criação de uma personagem está diretamente ligada às intencionalidades do enredo da trama, mas antes é fruto da imaginação de seu(sua) criador(a), aqui representado(a) pelos(as) autores(as) das telenovelas. Beth Brait (1993) ao descrever a influência do(a) escritor(a) na concepção de personagens de literatura explica que "como um bruxo que vai dosando poções que se misturam num mágico caldeirão, o escritor recorre aos artifícios oferecidos por um código a fim de engendrar suas criaturas" (BRAIT, 1993, p. 52).

Em telenovelas, a construção das personagens é especialmente importante pois existe uma tendência de que elas sejam priorizadas, característica herdada da tradição folhetinesca (NOGUEIRA, 2002). Em entrevista para o livro de Lisandro Nogueira (2002), Gilberto Braga, autor de telenovelas na Rede Globo, explicita como essa priorização dos seres fictícios influencia o seu processo de criação: "Primeiro procuro os personagens, não procuro histórias, não. Porque eu fico procurando

\footnotetext{
${ }^{10}$ Sobre a relação telenovela e contextos históricos brasileiros ver: Alencar (2002) e Borelli (2005).
} 
mesmo, que é o mais difícil de achar, é um personagem que leva aquela história" (NOGUEIRA, 2002, p.85).

Essa busca costuma receber atenção porque os objetivos das personagens principais ilustram a justificativa da existência da própria história (SADEK, 2008). Tendo fixado esse argumento que justifica as ações desses personagens, cabe ao(à) escritor(a) escolher as ações de suas criações guardando nexo com as proposições iniciais.

Esse pode ser um dos motivos para a presença recorrente nas telenovelas do que Pallottini (1998) define como personagem-sujeito. Nesse caso, há menos espaço para as variações no caráter e nos objetivos das pessoas em ficção, conforme explica: chamo de personagem-sujeito aquele que age, faz e diz coisas que the apraz dizer e fazer, como se tudo brotasse do seu interior, absolutamente livre, como se a fonte de suas ações e palavras fosse uma vontade totalmente independente de influxos externos, como se, enfim, ele fosse senhor de sua vida e atos, sua vontade tendo como correspondente e sua responsabilidade e nada mais (PALLOTTINI, 1998, p. 149).

A limitação temporal das obras também exige a eleição de um número restrito de características psicológicas, afinal, mesmo nas telenovelas, que ficam no ar durante meses, não seria possível dar conta da subjetividade de uma pessoa. O(a) autor(a) faz uma escolha de determinados traços entendidos como essenciais para que se consiga compreender suas criaturas (CANDIDO et al., 2007). Assim, torna-se justificável a repetição intensa de determinadas expressões e gestos.

As personagens, principalmente as protagonistas, aparecem em várias cenas ao longo de meses. Assim, a repetição de falas torna-se um recurso para que o(a) autor(a) consiga manter essa história, ainda que essa estratégia tenda a fazer com que sejam apresentadas personagens mais simplificadas (SADEK, 2008). Como afirma o autor, "o grande número de capítulos ou, se preferirmos, o número total de horas que uma telenovela leva para contar a história, mesmo com várias linhas dramáticas, impõe certo grau de redundância aos personagens” (SADEK, 2008, p. 96).

Mas essa necessidade não representa um aspecto limitador do trabalho de quem escreve, é, ao contrário, um fator que permite uma melhor apresentação dos aspectos fundamentais das personagens, fazendo com elas se tornem mais transparentes:

Precisamente porque se trata de orações e não de realidades, o autor pode alcançar aspectos essenciais pela seleção dos aspectos que apresenta, dando às personagens um caráter mais nítido do que a observação da realidade costuma sugerir, levando-as, ademais, através de situações mais decisivas e significativas do que costuma ocorrer na vida (CANDIDO et al., 2007, p. 35). 
Ao mesmo tempo, a extensão das tramas permite que, caso haja a necessidade de mudanças dos objetivos das personagens e, portanto, de suas características definidoras, esse processo seja lento, gradual e o mais natural possível (SADEK, 2008). Por isso, é importante demarcar que nas telenovelas, obras abertas, essa rigidez com relação às definições iniciais perde força. 0 caráter dialógico dessas obras permite que autores(as) possam fazer adaptações dos detalhes das personagens durante o curso das histórias.

A construção de personagens mais sinuosas envolve várias camadas e traços distintos e a apreensão dos(as) leitores(as) geralmente obedece ao seu nível de abstração. Dessa forma, é comum que existam vários sentidos atribuídos sobre uma mesma personagem. Na literatura, "dependendo de suas intenções e principalmente de sua perícia, ele [autor] vai manipular o discurso, construindo essas criaturas, que, depois de prontas, fogem ao seu domínio e permanecem no mundo das palavras à mercê dos delírios que esse discurso aos incontáveis receptores" (BRAIT, 1993, p. 67). Algo que pode ser ampliado para pensarmos a ficção televisiva.

A interpretação das personagens é subjetiva e pessoal. 0 intuito do(a) autor(a) ao dar a elas determinadas características não garante que o(a) receptor(a) irá compreendê-las da mesma forma como foram pensadas. Assim, além dessa diferença de leitura entre os polos da produção e da recepção, há entre o público que acompanha a obra uma variedade de níveis de formação e experiências que proporcionam visões variadas sobre uma mesma personagem.

Aos(às) protagonistas cabem os papéis de articuladores(as) das tramas, eles(as) funcionam como ponto de partida e fator desencadeante para boa tarde das histórias paralelas que acontecem em uma telenovela. Como é de se esperar, a esse tipo de personagem estão associados modelos de construção mais multifacetados.

A complexificação dos traços psicológicos das personagens foi uma das marcas do romance moderno e serviu como alternativa para a necessidade de simplificação da caracterização imposta por esse novo contexto. Assim, os enredos foram reduzidos e, como forma de compensação, as personagens passaram a ter mais detalhes sob o ponto de vista da psicologia (CANDIDO et al., 2007).

No século XX, a forma de pensar as personagens sofreu uma mudança e o aprofundamento das questões psicológicas aparece como um recurso ainda mais recorrente, principalmente quando as personagens pensam sua posição no mundo em relação às estruturas sociais. Essa tendência pode ser vista principalmente nas figuras centrais das obras, representadas pelos heróis:

0 herói problemático, também denominado demoníaco, está ao mesmo tempo em comunhão e em oposição ao mundo, encarnandose num gênero literário, o romance, situado entre a tragédia e a poesia lírica, de um lado, e a epopeia e o conto, de outro. Nesse sentido, a forma interior do romance não é senão o percurso desse ser que, a partir da submissão à realidade despida de significação, chega à clara consciência de si mesmo (BRAIT, 1993, p. 39). 
Estabelecidos os interesses dos(as) protagonistas surgem os(as) antagonistas, aos(às) quais costumou-se atrelar os papéis dos vilões ou vilãs e que têm como finalidade causar dificuldades na busca dos objetivos dos(as) protagonistas (PALLOTTINI, 1998). É a partir dessas definições iniciais que a história poderá ser desenvolvida.

Como vilões e/ou vilãs pretendem propor obstáculos no caminho dos(as) chamados(as) mocinhos(as), é necessária também que essas personagens tenham uma carga de vontade grande para a realização de suas ações, em alguns casos, até maior que os(as) protagonistas, o que às vezes, faz com que a movimentação da trama deixe de ser realizada por protagonistas (PALLOTTINI, 1998).

Historicamente, nas telenovelas, foi bastante frequente a associação das forças antagonistas em personagens específicas que sozinhas, ou apenas com ajuda de poucos(as) coadjuvantes, planejavam e executavam todos os planos que prejudicavam a trajetória dos(as) "mocinhos"(as). Por isso, ainda hoje é comum que sejam lembrados os papéis de grandes vilões e vilãs da história de obras nacionais e internacionais justamente por sua perversidade e o modelo de construção maquiavélico. Como possuem objetivos muito bem desenhados, esse pode ser entendido como um modo relativamente simplista na constituição psicológica.

Acompanhar a trajetória de vilões e/ou vilãs é também a espera pela realização de uma espécie de justiça. Antes mesmo do fim das telenovelas, é comum que se especule qual será o final merecido por essas personagens, já que o desfecho das tramas é momento em que elas devem "pagar" por todas as suas maldades. Quando isso não acontece, o(a) autor(a) geralmente tem de encarar as críticas que representam a frustação do público.

São esses alguns dos motivos que fazem com que os(as) antagonistas, principalmente os(as) que mais possuem traços de vilania, sejam destaque das telenovelas e que sua lembrança seja muito marcante, inclusive muito maior do que os(as) próprios(as) protagonistas.

Com o passar dos anos e as transformações das narrativas nas quais buscou-se adequar às novas exigências impostas pelo consumo, essa divisão maniqueísta parece perder espaço para protagonistas construídos(as) de maneira menos rígida em relação aos comportamentos, conforme explicam Fisher e Nascimento (2012):

Sai de cena o contorno nítido e maniqueísta de figuras claramente definidas, cedendo lugar ao esboço borrado dos espectros fugidios e voláteis que perfazem personas lacunares, multifacetadas, embrionárias. Valores do bem e do mal se inscrevem, diegeticamente, em personagens ambíguas, coincidentes, hibridizadas, que transitam por entre "vilanias" e "heroísmos" dos mais variados tipos. Assim, heróis e vilões entrelaçam traços, superpõem fundos, misturam tonalidades e criam/revelam as imagens multifocadas e plurais da contemporaneidade líquida e 
cambiante em que - na ficção e na dita realidade, na produção e na recepção - estamos todos inseridos enquanto protagonistas e coadjuvantes (FISCHER; NASCIMENTO, 2012, p. 744).

É interessante observar que a apresentação de construção de personagens com características mais determinadas não se aplica apenas em seu modo de ser, mas também em seu modo de agir. Ora, ajustar suas atitudes com sua essência é também uma forma de confirmar a coerência da obra. Desse modo, a maneira como essas personagens guiam seus relacionamentos tende a ser relativizada:

Os pares amorosos, a princípio, não se estabelecem com firmeza. Relações triádicas ou múltiplas articulam-se em relativa placidez e muitas vezes com o conhecimento e aquiescência dos envolvidos sem que esses sejam encaixados na categoria dos devassos e desajustados sexuais, pelo contrário: são apresentados como pessoas sensíveis, afetivas, conscientes de seus atos (FISCHER; NASCIMENTO, 2012, p. 744).

Embora esse movimento de diminuição das barreiras que separa os(as) bons/boas dos(as) maus/más venha ganhando força, a divisão maniqueísta e demarcação de algumas personagens como protagonistas e antagonistas parece ser um recurso ainda muito usual. Os poucos exemplos de autores(as) que fogem desse modelo de construção são pontais e muitas vezes, parecem confundir o público com relação aos lugares e ao caráter dessas personagens.

\section{AS NUANCES DE RITINHA}

No primeiro episódio de A Força do Querer, a trama de Ritinha que, segundo Gloria Perez, é o eixo central para o desenvolvimento dos demais núcleos ${ }^{11}$, é a última a ser apresentada, sendo que a própria personagem não tem nenhuma fala. Isso fez com que na estreia, essencial para a apresentação da narrativa, a autora caracterize a protagonista através das falas de outras personagens. Estratégia que é comum e potente no caso das telenovelas, como ensina Brait (1993).

Ritinha era uma jovem que morava com sua mãe, Ednalva (Zezé Polessa), na cidade fictícia de Parazinho, no norte do país, de onde ela nunca havia saído. Por conta disso, tinha muita curiosidade em conhecer outros lugares e enxergava no relacionamento com Zeca (Marco Pigossi), um caminhoneiro que havia crescido na vizinhança, a oportunidade de realizar esse desejo. Demarca-se então, logo no início da narrativa, a primeira ligação com as protagonistas escritas anteriormente por Gloria Perez.

11 Disponível em: https://istoe.com.br/gloria-perez-fala-de-a-forca-do-querer-trama-que-elevouaudiencia-dohorario/ Acesso em 22 de Abr. 2020. 
Esse namoro de Ritinha, por outro lado, não agradava ao pai de Zeca, Abel (Tonico Pereira), que sempre se preocupou com o caráter da moça. Esse medo era explicado pelo que ele entendia como a natureza não-humana da jovem que, de acordo com Ednalva, era filha do boto. Isso fazia com que Abel temesse a imutabilidade da personalidade da garota e as consequências que poderiam ser causadas por conta da grande atração que o filho sentia por ela:

\section{Cena do capítulo 1}

(Após Zeca ter saído de casa para ver Ritinha, Abel conversa com sua irmã)

Abel - Viu? Já vai atrás de dela.

Nazaré - Mas tu não fazes gosto mesmo hein, Abel.

Abel - Ela não serve para ele! Nem para ele, nem para ninguém. Zeca fica lesado com a "boniteza" dela. Não enxerga, não enxerga, não enxerga.

Nazaré - A menina é muito nova, Abel. Às vezes ela muda.

Abel - A natureza da pessoa não muda, não, Nazaré. Olha, você sabe como eu sou doido por essa terra, não sou? Pois é, mas para distanciar o Zeca da Ritinha, eu ia-me embora de uma vez. Eu só tenho ele, eu me viro do avesso para ter ele feliz, para ver ele feliz.

É necessário explicar que a personagem acreditava ser uma criatura mítica por conta da suposta origem de seu pai. Durante a história, ela trabalhou vestida como uma sereia em alguns aquários pois acreditava ser essa sua vocação. Apesar de não ficar claro se essa existência mítica era verdadeira, o símbolo da sereia e as ações que lhe são características, como a sedução, foram mobilizados em algumas situações. Esse encanto que sua beleza despertava nos homens era conhecida e explorada por Ritinha. Em suas falas, a personagem reiterava como era interessante a sensação de se sentir desejada.

Outra característica sustentada pelas falas da personagem e que não por acaso se liga ao argumento central da obra era a obstinação para satisfazer seus "quereres". A problemática, nesse caso, se dava porque ela não parecia se importar com as consequências trazidas pela realização dessas vontades.

Quando conhece Ruy (Fiuk), acontece a primeira grande mudança em sua trama. Ele era um empresário que se interessou por ela durante uma visita em Parazinho (localizada no estado do Pará). Como forma de conquistá-la, ele afirma que poderia a levar para conhecer o Rio de Janeiro e ela se empolga com a possibilidade. A questão é que os(as) moradores(as) comentam sobre os encontros dos dois a ponto de fazerem Zeca acreditar que estava sendo traído. Após serem ameaçados por ele, Ritinha e Ruy decidem fugir para o Rio de Janeiro.

Cabe esclarecer que a ligação entre Zeca e Ruy começa a ser desenhada logo no primeiro capítulo, quando são mostrados na primeira fase da história se afogando 
juntos no rio de Parazinho durante a infância. Em seguida, aparecem desacordados na beira do rio e são resgatados por um índio. Quando acordam, eles revelam ter tido um mesmo sonho, que é interpretado pelo índio como um aviso para que eles tivessem cuidado com o que viesse das águas e que o rio que os uniu irá separá-los novamente. Logo em seguida os anos passam e eles são mostrados já adultos. Nessa fase, os dois não possuem nenhum contato e sequer se conhecem. Zeca permanece morando em Parazinho e Ruy no Rio de Janeiro.

Na segunda fase da trama, Ritinha decidiu esconder que esperava um filho com Zeca quando fugiu de Parazinho. Ao chegar na cidade carioca com Ruy, mentiu e afirmou que a criança que esperava era filha dele. Nesse momento da história, há um bom exemplo de como a personagem não media as consequências de suas ações, estando apenas focada na finalidade a ser alcançada. Nesse caso, isso significava assegurar seu casamento com Ruy e a permanência no Rio de Janeiro.

A estratégia dá certo. Além da gravidez, Ruy se sente cada vez mais envolvido por Ritinha até que decide romper seu noivado com Cybele (Bruna Linzmeyer) e se casar com ela. Em Cybele, encontra-se uma possível relação de antagonismo. Porém, essa possibilidade fica invalidada, já que suas ações não são capazes de estabelecer grandes entraves na trajetória de Ritinha. Cabe a Cybele, por exemplo, a descoberta sobre a paternidade do filho que supostamente seria de Ruy e o esforço para que ele soubesse a verdade. No entanto, mesmo depois de descobrir o segredo, Ruy não desiste do relacionamento com Ritinha, o que seria o objetivo de Cibele.

Após se casar, a protagonista passa a morar com a família do marido, que vive em um apartamento luxuoso. Seus modos de se vestir e de se comportar passam a ser pontos de conflito na relação com a família, sobretudo por conta Joyce (Maria Fernanda (ândido), sua sogra. Acostumada a estampar as capas de revista de moda, Joyce se empenha em tentar fazer com que Ritinha se torne mais parecida com sua família, algo que não funciona, porque a jovem não sentia vergonha de suas origens, mesmo com sua vontade de conhecer o mundo. Pelo contrário, sempre exibia orgulhosa os detalhes da cultura de sua cidade natal. Essas manifestações reforçaram a imutabilidade de personalidade como um de seus traços fundamentais.

Esse traço contínuo, por outro lado, era o motivo pelo qual ela se via em meio a situações complicadas, das quais não tinha o controle. Evidência que ajuda a compreender como as problemáticas em sua trajetória não eram criadas por uma figura antagonista, mas por uma espécie de relação causa-efeito entre suas próprias atitudes, acompanhadas de uma espécie de conhecimento tácito do público sobre a protagonista, permitindo que situações e personalidade fossem compreendidas e reconhecidas.

Outra marca do discurso de Ritinha estava na busca por justificar suas falhas de comportamento nas atitudes de outras personagens. Visão compartilhada pela sua mãe que, apesar de reconhecer um comportamento intempestivo na filha, o atribuía aos comentários que outras personagens faziam sobre ela. Mais objetivamente, ela 
reiterava algumas vezes que as pessoas sentiam inveja, faziam intrigas sobre a filha e seria essa a razão que fazia com que ela se comportasse de tal maneira.

Algumas personagens interpretam essa constância das características de Ritinha como algo perigoso para quem a cercava. Essa visão é defendida em especial por Abel, como já mencionado, e, mais tarde, por Joyce.

A opinião de Joyce estava mais fundada na observação que ela fazia das atitudes de Ritinha e, principalmente, em uma espécie sensação intuitiva. Joyce afirma por diversas vezes que apesar de não conseguir verbalizar os motivos que a levam a pensar dessa forma, sentia que Ritinha representa um perigo para sua família e que a sua presença na casa ainda poderia trazer malefícios a todos(as). Somente nos capítulos finais, após Ruy ter atirado em Zeca por conta de ciúmes, Joyce passa a compartilhar da opinião de Abel de que Ritinha está associada à profecia do índio:

\section{Trecho de cena do capítulo 168}

(Joyce conversa com Zu e Ivan enquanto ocorre o julgamento de acusação de Ruy por conta do disparo contra Zeca)

Joyce - Essa Ritinha foi um desastre na vida da gente.

Ivan - Cês tão falando da Ritinha?

Joyce - É nessa hora que me vem aquela sensação horrível de quando o Ruy quase morreu afogado. A profecia daquele índio

Ivan - Mãe, você sempre cismada com essa história. O Ruy lembra bem o que o índio disse. Ele não previu nenhum tsunami na vida dele. Joyce - Alertou para um perigo, mandou tomar cuidado com o que vinha das águas. Não mandou?

Ivan - Ele também não tá embarcando em nenhum Titanic, né? A não ser no sentido figurado.

Joyce - Ritinha diz que é uma sereia. Sereia não vem das águas?

$\mathrm{Zu}$ - Dona Joyce...

Ivan - Mãe, também não força, né. Bom, eu tô indo lá.

Zu - Vai, vai dar um apoio ao seu irmão.

Ivan - Tá.

Joyce - Vocês acham que tô viajando, não é? Pode ser. Mas pode ser que não.

Zu - O que eu tô achando esquisito é Ruy tá tão agoniado, sentindo como se tivesse de novo aquele afogamento. Falando que tá sentindo que pode acontecer outra coisa com ele.

Sobre a maternidade, o texto explora uma camada menos irresponsável da personagem. Isso ocorre porque ela demonstrava muito carinho pelo filho e, quando foi forçada a permanecer distante dele, suas falas assumem um tom mais dramático. Ela reitera que era injusto ser afastada da criança pois afirma, algumas vezes, por exemplo, que o filho era dela, não de Zeca e nem de Ruy. 
Durante os episódios em que permanece afastada de seu filho por conta de questões judiciais, o apoio que recebe de outras personagens - inclusive nos vídeos feitos em sua campanha na internet e na televisão para recuperar a guarda da criança - reforça essa ideia. Nessa situação, a autora demarca essa posição ao escrever falas de apoio para personagens que não possuíam uma visão positiva sobre ela, mas que cedem e se solidariam com a sua dor.

\title{
Trecho de cena do capítulo 163
}

(No hospital, Abel e Zeca conversam sobre a situação da guarda de Ruyzinho, filho de Ritinha)

\begin{abstract}
Abel - Deixaram o tal do Ruy responder o processo em liberdade. 0 “disgramado" não ficou nem preso. É coisa de rico mesmo.

Zeca - Égua. Eu quero mais é que se lasque aquele lá.

Abel - Agora não quer mais que a Ritinha bote os olhos no menininho, não. Não quer.
\end{abstract}

Zeca - Não quer não, é?

Abel - Ganharam até a tomada de conta da criança. A filhotinho de cobra tá que tá pra morrer. Eu confesso que eu até me compadeci dela. Me compadeci.

Zeca - Mas também é muita ruindade. Né, não?

Abel - Não é?

Zeca - É muita ruindade. Ela pode não prestar mesmo, mas... mas também o menino é dela, nasceu de dentro dela. Né, não?

Zeca e Ruy demonstram ter um posicionamento parecido em relação à Ritinha. Zeca, por exemplo, depois do episódio em que a viu fugir de Parazinho com Ruy, passa grande parte da trama afirmando que não gosta mais da ex-noiva e que ela seria, na verdade, muito pior do que as outras pessoas afirmam. Mas sua fala entra em contradição em vários momentos. Existem cenas em que ele conversa com a imagem de Nossa Senhora de Nazaré, em seu quarto, quando ninguém ouve, e questiona seus sentimentos por ela.

Ruy, por sua vez, negou que gostava dela no início da história. Durante a trama cogita se separar algumas vezes, mas sempre acabou demonstrando interesse em reatar, apesar de não concordar com alguns comportamentos dela.

Há, portanto, uma outra possibilidade de interpretação dos discursos que produzem sobre a protagonista - e que é possível por conta desse encantamento que ela causa neles e que os faz perdoar suas faltas mais graves: a metáfora da sereia. A visão que eles têm sobre ela segue um caminho semelhante. Inicialmente, os dois afirmam que se sentiram atraídos por ela assim que a conheceram. Durante o relacionamento, seguem sem entender os motivos pelos quais as outras personagens enxergam Ritinha como perigosa ou egoísta, mesmo depois de se decepcionarem de alguma forma. Nos últimos capítulos, inclusive, eles a procuram e se mostram 
dispostos a reatar o relacionamento com ela mesmo após vários desapontamentos com a personagem.

\section{Cena do capítulo 172}

(Em Las Vegas, depois de Ruy e Zeca terem visto juntos Ritinha no aquário. A cena se passa no quarto em que ela está hospedada.)

Ritinha - Égua. Eu gostei foi muito de saber que vocês pararam de se intrigar. Vocês dois. Agora, ó, Ruyzinho não vai levar, não.

Porque Ruyzinho é meu.

Zeca - É seu. É seu mas é meu também que ele é meu filho.

Ruy - Ele é meu filho também. Por direito, Ritinha, mas é meu filho também.

Zeca - Tu voltas com a gente.

Ritinha - Volto nada!

Zeca - Volta.

Ritinha - Volto não que eu volto depois. Agora vou voltar, não.

Nasci para ficar presa, não. Tô é gostando daqui. Olha isso aqui. Eu gosto de vocês dois, mas eu gosto mais de mim.

Ruy - Como é que você veio para cá hein, Ritinha?

Ritinha - Eu? Aquele repórter, amigo da tua mãe, falou pra mim que se eu quisesse, ele me trazia pra cá. Aí eu procurei ele com Ruyzinho, eu mais pedacinho... e vim embora para cá com ele. Assim.

A relação com os pares românticos serve para reafirmar o gosto pela liberdade da personagem. A autora explora bem a busca pela auto-realização de Ritinha ao escrever um final onde ela permanece sozinha, criando o filho - após ter saído do país com o menor sem autorização judicial, trabalhando e sem a companhia de Zeca ou Ruy. Em suas falas, Ritinha explica que a ideia de um relacionamento passou a soar como sinônimo da perda de sua liberdade e que, como gostava mais de si mesma, preferiu permanecer solteira.

Ao levar a busca pela independência como um dos objetivos definitivos da personagem Gloria Perez demonstra mais uma vez que decidiu fazer com que a protagonista se mantivesse com boa parte das motivações que a guiaram desde o início da trama. Há também a criação de um modelo de identificação feminino que não necessitou de uma relação conjugal como requisito para um final feliz. 0 caminho para esse desfecho, ainda que baseado em mentiras e de fugas diante dos problemas, revela que essa "mocinha" não possui apenas características consideradas boas, mas sim, que se baseou em uma construção mais profunda com camadas psicológicas variadas. A trajetória da personagem, nesse sentido, ao mesclar coerências e traços disruptivos, coloca-a numa situação de desvio. E tal aspecto "desviante”, menos que chamar a atenção para uma ruptura frente a outras 
"mocinhas" da ficção seriada televisiva, coloca em cena a complexidade de sua construção como protagonista e, dessa forma, evidencia aspectos de marcas autorais. No caso, as de Gloria Perez.

\section{CONSIDERAÇÕES FINAIS}

Observada a trajetória de Gloria Perez e as marcas de sua autoralidade no tensionamento com a estruturação e desenvolvimento de uma telenovela, percebese que a autora pratica um modelo de construção de personagem, através de suas protagonistas, que se distancia, historicamente, da herança melodramática, que tende a separar as personagens protagonistas como boas ou más, construindo uma nova proposição, aqui considerada como uma protagonista desviante. Esse modelo é construído a partir de traços psicológicos mais profundos que são as premissas para que essas personagens tenham ações menos óbvias, como é o caso de Ritinha. Algo que, certamente, não se refere a uma qualidade estética ou essencial de sua composição, fechada e restrita à uma trama "em si". Como afirma Simões (2005, p. $3)$,

na medida em que as narrativas ficcionais tomam a realidade como ponto de partida na construção de seus mundos possíveis, estes revelam alguns aspectos e características de um real situado em um tempo e lugar específicos. A partir disso, é possível afirmar que as obras ficcionais constróem representações que se referem a ou dialogam com a realidade em que estão inscritas, mas não podem ser entendidas como espelhos do real.

A construção das protagonistas, em Gloria Perez, está carregada com os traços utilizados pela autora, como identificado por Gomes (2013), em suas personagens centrais das telenovelas anteriores e na atualização de uma relação, também complexa, entre ficção televisiva e vida social. Na trajetória dos roteiros que edificam tais personagens, são exemplares o seu gosto pela liberdade, o desejo em conhecer variados locais, a juventude, a inconsequência e o tipo de relação que uma ou outra personagem constrói com a maternidade. Isso revela as tensões entre realidade e ficção e como uma trama, no âmbito televisivo ficcional, aciona modalidades e dinâmicas para dar vida a personagens "menos redondos" que requerem uma duração temporal (pela serialidade de suas histórias, em capítulos) e personificação (algum tipo de aprofundamento de personalidade e composição coerente de identidade, a ponto de esta poder ser reconhecida por um público, mesmo que de forma fragmentada).

Ritinha, em A Força do Querer (2017), amplia esse rol "desviante" frente às suas antecessoras em alguns pontos. Não trabalha em busca de uma forma de ajudar sua família, mas por acreditar na sua relação biológica com as águas (por ser filha do boto) e por the agradar o fato de ser admirada pelo público. Outro ponto de 
diferenciação marcante é a maneira como lida com as questões amorosas. Ao contrário das outras protagonistas, Ritinha não assume um posicionamento convencional nos relacionamentos amorosos como as personagens anteriores. Com ela, Gloria Perez escolheu acentuar ainda mais o amor próprio e a obstinação da personagem na busca de sua realização pessoal.

Gloria Perez apresenta propositalmente uma série de leituras possíveis diante da maneira com que compôs essa personagem, por meio das falas das demais em $A$ Força do Querer. 0 desfecho da telenovela é essencial para entender essa posição, já que Ritinha não é punida por ser bígama e nem por ter fugido com o filho enquanto ele tinha a guarda compartilhada com Ruy, como seria usual no caso de uma vilã. Ela também não termina a trama ao lado de um par romântico e sua realização está somente relacionada aos seus desejos, como também não seria comum para uma "mocinha".

Apesar disso, não se nega seu lugar de personagem que traz consigo um residual do protagonismo construído por Perez em sua história e no contato de sua singularidade autoral com a sociedade. De alguma forma, Ritinha mistura temporalidades de uma autoria e de uma época, o que a faz desviante não exatamente por aquilo que parece romper, mas por aquilo que ela sugere ampliar como agente da e em narrativa. A partir dela, pode-se voltar e realizar novas leituras sobre obras do passado assim como projetar interpretações acerca de personagens futuros. Trata-se, assim, de um ponto de interseção entre tempos autorais, cujo interpretação, metodologicamente, aponta para caminhos de leitura acerca de protagonistas, autores(as) e contextos.

\section{REFERÊNCIAS}

ALENCAR, Mauro. A Hollywood brasileira: panorama da telenovela no Brasil. São Paulo: 2002, SENAC.

BORELLI, Silvia Helena. Telenovelas: padrão de produção e matrizes populares. In: BRITTOS, Valério; BOLAÑO, César. (Orgs.). Rede globo: 40 anos de poder e hegemonia. São Paulo: Paulus, 2005.

BRAIT, Beth. A personagem. 5. ed. São Paulo: Ática, 1993.

CANDIDO, Antonio et al. A personagem de ficção. 11. ed. São Paulo: Perspectiva, 2007.

FISCHER, Sandra; NASCIMENTO, Geraldo Carlos do. Vilões, Heróis e Lugares na Telenovela Brasileira Contemporânea: A Favorita e Insensato Coração. Revista Comunicación, Sevilla, v.1, n. 10, p.743-754, 2012. 
GOMES, Juliana Oliveira. Arebaba! Telenovela e autoria. Caminho das Índias, Gloria Perez e os relatos de migrantes e viajantes. Dissertação (Mestrado). Universidade Federal da Bahia, Programa de Pós-Graduação em Comunicação e Culturas Contemporâneas, Salvador, 2013.

LOPES, Maria Immacolata Vassallo. Telenovela como recurso comunicativo. Matrizes (USP. Impresso), v. 3, p. 21-48, 2009.

MEMÓRIA GLOBO. Barriga de Aluguel - Galeria de Personagens. Disponível em: http://memoriaglobo.globo.com/programas/entretenimento/novelas/barrigademaluguel/galeria-de-personagens.htm Acesso em: 22 de Abr. de 2020.

MEMÓRIA GLOBO. De Corpo e Alma - Galeria de Personagens. Disponível em : http://memoriaglobo.globo.com/programas/entretenimento/novelas/de-corpo-ealma/galeriade-personagens.htm Acesso em: 22 de Abr. de 2020.

MEMÓRIA GLOBO. Explode Coração - Trama Principal. Disponível em: http://memoriaglobo.globo.com/programas/entretenimento/novelas/explodecoracao/tramaprincipal.htm Acesso em: 22 de Abr. de 2020.

MEMÓRIA GLOBO. Gloria Perez - Trajetória. Disponível em: http://memoriaglobo.globo.com/perfis/talentos/gloria-perez.htm Acesso em: 22 de Abr. de 2020.

MEMÓRIA GLOVO. O Clone - Trama Principal. Disponível em: https://memoriaglobo.globo.com/entretenimento/novelas/o-clone/tramaprincipal/ Acesso em: 22 de Abr. de 2020.

MEMÓRIA GLOBO. Salve Jorge - Trama Principal. Disponível em: https://memoriaglobo.globo.com/entretenimento/novelas/salve-jorge/tramaprincipal/ Acesso em: 22 de Abr. de 2020.

NOGUEIRA, Lisandro. O autor na televisão. Goiânia: Ed. da UFG, 2002.

PALLOTTINI, Renata. Dramaturgia de televisão. São Paulo: Moderna, 1998.

PICADO, Benjamin; SOUZA, Maria Carmem Jacob. Dimensões da autoria e do estilo na ficção seriada televisiva. MATRIZES (ONLINE), v. 12, p. 53-77, 2018.

SADEK, José Roberto. Telenovela: um olhar do cinema. São Paulo: Summus, 2008. 
SANTANA, André. Caminho das Índias estreava há nove anos. Disponível em: https://observatoriodatelevisao.bol.uol.com.br/historia-da-tv/2018/01/caminhodas-indiasestreava-ha-nove-anos Acesso em: 22 de Abr. de 2020.

SANTANA, André. Há 13 anos, estreava a novela América. Disponível em: https://observatoriodatelevisao.bol.uol.com.br/historia-da-tv/2018/03/ha-13anos-estreava-anovela-america Acesso em: 22 de Abr. de 2020.

SIMÕES, Paula Guimarães. Representações do amor no diálogo entre ficção e realidade: telenovela e sociedade brasileira. In: Anais do XXVIII Congresso Brasileiro de Ciências da Comunicação (INTERCOM). Rio de Janeiro: Imprinta Express Ltda, 2005. p. 1-15.

SOUZA, Maria Carmem Jacob. Analisando telenovelas. Rio de Janeiro: E-papers Serviços Editoriais, 2004.

TEIXEIRA, João Senna. SOUZA, Maria Carmem Jacob. Princípios e recursos da continuidade narrativa na serialidade dos comics de super-heróis. REVISTA FRONTEIRAS, v. 21, p. 130-141, 2019.

XAVIER, Nilson. Carmem - Sinopse. Disponível em:

http://teledramaturgia.com.br/carmem/ Acesso em: 22 de Abr. de 2020. 